\title{
Exploring the spatio-temporal processes of communal rangeland grabbing in Sudan
}

\author{
Hussein M. Sulieman
}

\begin{abstract}
The persistent policy of successive Sudanese governments in favouring large-scale agricultural investments at the expense of traditional land use is creating material differences among significant groups of the population. A significant share of this type of investment falls within the territories of the communal rangelands of the country. The aim of this paper is to provide analytical insights of the geographical allocation and the temporal evolution of land grabbing on the expanses of communal land utilized by local inhabitants in Butana area in eastern Sudan. The study relies on multi-temporal Landsat satellite imagery (2000, 2005, 2009, and 2014), ground surveys, and key informant interviews. The results show that large-scale mechanized agriculture (LSMA) in Butana communal rangeland increased incrementally from 2.5\% in 2000 to 17.6\% in 2014. The starting location of the expansion of LSMA was in surrounding valleys. From the images, it is clear that land grabbing is converting the natural vegetation cover of Butana communal rangeland into spatially fragmented patches. Large-scale farmers (LSFs) involved in the process included wealthy pastoralists who own large numbers of livestock and absentee farmers who rely on hired representatives to manage their agricultural operations. Without a fundamental change in governmental policy, which currently turns a blind eye to the illegal activities of LSFs on communal rangeland, the gloomy scenario of land-based conflict may erupt in the eastern part of the country.
\end{abstract}

Keywords: Butana rangeland, Land-use, Mechanized agriculture, Livelihood, Rangeland fragmentation, Sudan

\section{Introduction}

The ever-increasing demand for land resources is reshaping landscapes all over the global south at an unprecedented rate. This is due to a misconception that the economic benefits of large-scale investment will exceed those of pre-existing traditional production systems, such as pastoralism (Behnke and Kerven 2013). Catley et al. (2013) found that the primary motivations of African governments which allow land grabbing are to raise tax revenue and to exert greater control over economic and political activities in pastoral areas. However, the losses caused by this large-scale development exceed - or diminish considerably - the gains (Schlee 2013). Among the most visible adverse implications are the following: loss and fragmentation of rangelands, induced sedentarization of pastoralists and radical reduction in livestock numbers (Abbink et al. 2014), and breakdown of customary social systems and social insecurity (Ahmed 2008; Sulieman

Correspondence: hmsulieman@yahoo.com

Centre for Remote Sensing and Geographical Information Systems, Faculty of Agricultural and Environmental Sciences, University of Gadarif, P. O. Box 449, 32211 Gadarif, Sudan

(c) The Author(s). 2018 Open Access This article is distributed under the terms of the Creative Commons Attribution 4.0 International License (http://creativecommons.org/licenses/by/4.0/), which permits unrestricted use, distribution, and reproduction in any medium, provided you give appropriate credit to the original author(s) and the source, provide a link to the Creative Commons license, and indicate if changes were made.
2015). According to Krätli et al. (2013), unless investments are made to develop pastoralism rather than to replace it, the threats to food security will go beyond the boundaries of the drylands.

The residents of the pastoral and agro-pastoral communities situated in these emerging areas of investment engage in smallholding cultivation within larger socioeconomic networks; they are and will continue to be seriously affected by large-scale commercial investment, both domestic and foreign (Sulieman 2015). The rational use of rangelands through mobile livestock husbandry has long been defined as the most effective strategy for extracting value out of otherwise marginal lands (Galaty 2013; Abbink et al. 2014). As a result, in contrast to large-scale mechanized agriculture (LSMA), pastoralism maintains and secures livelihoods in these marginal lands (Krätli et al. 2013). Babiker (2008) summarized that increasing scarcity of land in the presence of high rates of population growth, along with a historical legacy of discrimination and highly unequal land access, implies 
that many past and contemporary conflicts in Sudan have their roots in disputes over land.

Land grabbing in Sudan is capturing international attention for many reasons. The current wave of agricultural investment in the marginal rangeland of Sudan posts new challenges, especially the encroachment of large-scale agriculture which has been identified as a major contributor to conflict in many parts of the country (Pantuliano 2007). The conversion of rangelands into LSMA in central and eastern Sudan dated back to eighteenth century (Bernal 1997), and by the beginning of this century, the area under LSMA covered more than 10 million ha (UNEP 2007). Historically, the development of land legislation in Sudan has played a significant role in facilitating the grabbing of communal land. In recent history, the Unregistered Land Act of 1970 followed by the abolition of a native administration in 1971 provided the state the legal right to control communal land and remove any chance of legal redress against the state (Sulieman 2015; Elhadary 2010). Most recently, the implementation of the $2013 \mathrm{Na}$ tional Investment Encouragement Act further ensures a comfortable environment for and eliminates most of the constraints in the investment process (Elhadary and Abdelatti 2016).

Although Sudan has been ranked among the countries that have large pastoral population size (Markakis 1998; Egemi 2008), it stands as a distinct example of the failure of a state to secure the rights of pastoralists (Babiker 2008; Sulieman 2015). After totally occupying land designated for large-scale agriculture, LSMA in Sudan has been encroaching into the semi-arid regions of the country, which are recognized as excellent rangelands and traditionally managed as communal natural resources (Sulieman 2015). Moreover, Sudan has been identified as particularly vulnerable to the effects of climate change in Africa (Müller et al. 2014). Under such conditions, LSMA in marginal areas for agricultural production such as the semi-arid land of Butana is expected to accelerate the process of land degradation.

The land-use planning report of the Southern Kassala Agricultural Project (SKAP 1992) cautioned against the spread of LSMA in Gadarif State onto land which is marginally suitable in terms of environmental protection and agricultural sustainability. The report recommended confining agriculture to already demarcated limits and trying to improve productivity through proper husbandry rather than by horizontal expansion. Earlier work by Vitanen (1982) showed that the spread of agriculture to areas with little or uncertain rainfall was the main cause of desertification in North Kordofan, western Sudan. The ploughing of dryland pastures has resulted in desertification mainly by wind erosion. The loss of pasture has led to increased pressure on remaining pastures.
Despite a wide discussion on the issue of land grabbing in Sudan (World Bank 2010; Cotula 2011; Deininger et al. 2011) and continuous mention in the media and news headlines, scant empirical evidence exists on the spatial allocation and temporal evolution of the process. Elhadary and Abdelatti (2016) stated that 'due to the secret nature and lack of transparency in the process of land grabbing, having accurate and up-to-date data is far dreaming'. Babiker (2013) mentioned that 'details of recent land deals are notoriously difficult to identify yet Sudanese and international media report that over two million ha of land are 'up for grabs' in ongoing deals ...'. To provide empirical evidence to better inform the debate, this paper focuses on Butana communal rangeland in eastern Sudan which is classified as marginal for agricultural production and where by law LSMA activities are illegal (Sulieman 2015). The aim of this paper is to provide analytical insights of the geographical allocation and the temporal evolution of land grabbing on the expenses of communal land utilized by local inhabitants in Butana area in eastern Sudan. The specific objectives are (1) to detect the spatial and temporal processes of rangeland grabbing due to the expansion of large-scale mechanized agriculture (LSMA) and (2) to identify the main characteristics of the farmers involved in the process.

\section{Study area}

Butana communal rangeland is located in eastern Sudan and is part of Gadarif State (Figure 1). It is characterized by distinct seasons, which results in significant variability in the spatio-temporal distribution of grazing resources. Rainfall varies remarkably in incidence, intensity, and distribution over the entire area. Precipitation occurs during a three-month period from approximately midJune to mid-September. Total annual rainfall varies from about $75 \mathrm{~mm}$ in the northern parts to about $400 \mathrm{~mm}$ in the south. The Butana rangeland is a gently undulating plain. Contour isohyets show a marked change in direction and density along the boundaries between valleys (Figure 1). Lush grass cover makes the Butana rangeland excellent pasture. The compact nature of the clay soils that cover most of the Butana accelerates runoff, increasing soil erosion and encouraging the domination of annual grass species. Acacia shrubs grow around the few hills and in narrow belts along seasonal water sources. Vegetation patterns appear linked to water supply, topography, and soil.

Following the introduction of the 1970 Unregistered Land Act and the collapse of the Dar system (Dar is the homeland or territory of a specific tribe as defined by customary rights), it was, in 1971, possible for any pastoral group from different surrounding regions to enter the Butana area, making the Butana rangeland a key resource for mobile pastoralists in eastern Sudan. In each 


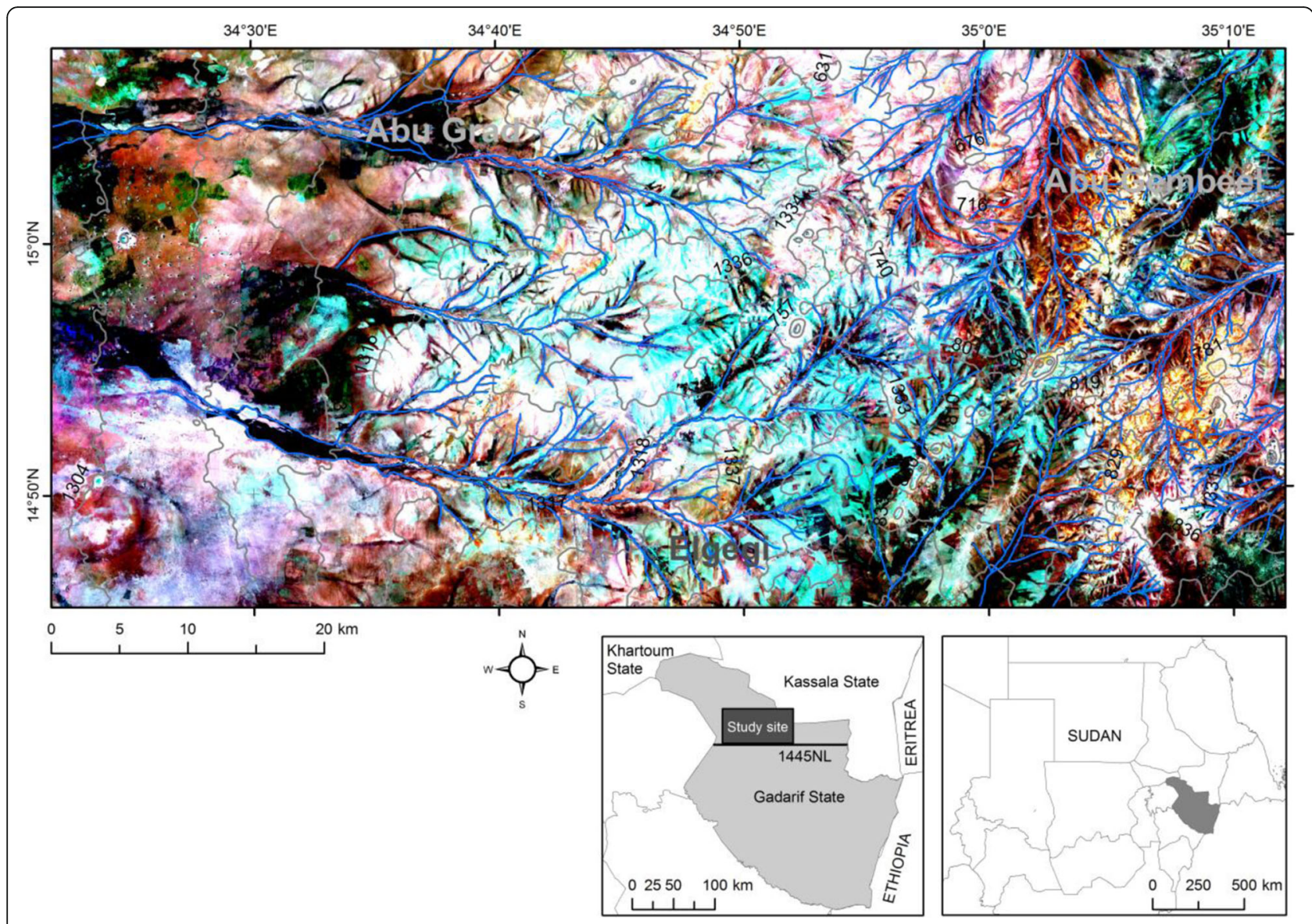

Figure 1 Location of the study area

rainy season from July to October, thousands of pastoralists from neighbouring states come to the area for the excellent quantity and quality of the grasslands (Sulieman and Ahmed 2016). Given the semi-arid nature of the region which makes it marginal for agricultural production, people who settled in Butana practised smallscale cultivation in areas along valleys and seasonal water sources for the comparatively better soil and moisture conditions. In recent decades, people of Butana have gradually shifted from long-distance pastoral movements to transhumance (Casciarri 2002). The changing distribution of grazing resources under the rapid expansion of LSMA is continuously shaping the pastoral mobility patterns (Sulieman 2015).

\section{Investigation site}

Selection of a site (Figure 1) that would show the evolution of LSMA in Butana was based on field visits and discussion with the Mechanized Framing Corporation (MFC), the governmental office responsible for leasing land for mechanized farming in Gadarif State. Accordingly, an area of about $92 \mathrm{~km} \times 42 \mathrm{~km}$ was chosen. The main valleys in the site are the Elgegi, Abu Gembeel, and Abu
Grad. The three valleys lie immediately to the north of the $14^{\circ} 45^{\prime} \mathrm{N}$ latitude (1445NL), the northern border of LSMA according to the regulations of the MFC in Gadarif State. Any LSMA is prohibited north of this line, which represents the official boundary between LSMA and Butana communal rangelands.

\section{Methods}

The time frame for this study is 2000 to 2014, the period when LSMA investments started and, thereafter, flourished in the region. Until 2000, there was no broad expansion of LSMA in Butana; therefore, imagery from this date has been used as a benchmark. Within this period, four dates of image acquisition were chosen: 30 October 2000, 28 October 2005, 21 September 2009, and 29 October 2014. The period from September to October is the most suitable time of year to distinguish between natural grass cover and areas cultivated by crops. The green-up of the natural vegetation in Butana starts in mid- to late July and lasts to November, while cultivation activities normally start mid- to late August and the collection of harvest begins in December. Imagery sets are from Landsat sensors and were 
collected from the United States Geological Survey (USGS) using its Global Visualization Viewer tool. Information on the sources and characteristics of the satellite imagery are available through http://glovis.usgs.gov/. The improved version of Shuttle Radar Topography Mission (SRTM) Digital Elevation Model (DEM) used was provided by the Global Agricultural Research Partnership (http://www.cgiar-csi.org/data/srtm-90m-digitalelevation-database-v4-1) at $90 \mathrm{~m} \times 90 \mathrm{~m}$ resolution.

A primary tool used to identify the LSMA sites on the satellite imagery was an on-screen digitizing technique based on the physiognomic attributes of objects and their spatial relationships or associations (Campbell 2006). Examples of physiognomic attributes included shape, size, colour, texture, and pattern. Also, the digitizing experience benefited from spatial relationships or associations of different natural and artificial objects such as water sources and road networks. Prior to use of this technique, both unsupervised and supervised image classifications were tried. Both image classification techniques provided indistinct boundaries of LSMA sites and spectral confusion - common in areas of sparse vegetation cover due to high background reflection from the soil, as is the case in Butana - led to mislabeling of land classes. Although time-consuming, onscreen digitization proved to be adequate for image interpretation processes in many situations (Alkan et al. 2010; Laliberte et al. 2011; Al-Bilbisi 2012; Disperati et al. 2015). The accuracy of the on-screen digitizing was checked using ground-truthing points collected with handheld GPS device collected during the ground survey.

Ground surveys and key informant interviews were conducted during April and August 2015 and combined with earlier field work (Sulieman 2015). The reconnaissance field surveys were conducted during April and August 2015 to gather field evidence on land grabbing including soil degradation and changes in plant species composition. During the field survey, ground-truthing data were collected using a handheld GPS device for the identification of LSMA. Panoramic photos (Figure 2) were taken to give an impression about some LSMA sites in Butana. To understand the social aspects of the expansion of the LSMA in Butana, interviews were held with eight key informants from local communities. Questions were centred around historical background of land grabbing, factors that led to the encroachment of large-scale agriculture, LSFs involved in the process, and spatial and temporal patterns of the phenomenon.

\section{Results}

The spatio-temporal expansion of LSMA in Butana communal rangeland

The pie chart shown in Figure 3 and maps presented in Figure 4 depict the graphical patterns of evolution of LSMA in Butana during the period 2000 to 2014. Through the study period, the percentage of area under cultivation in Butana rangeland increased from $2.5 \%$
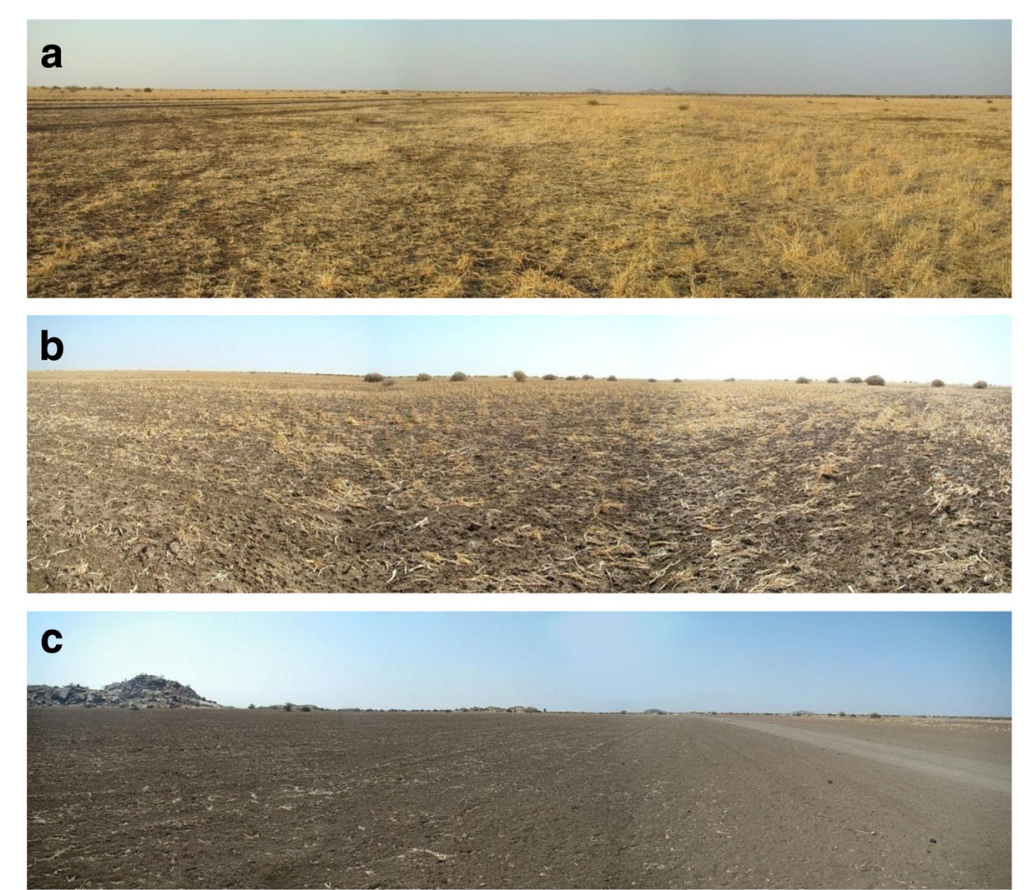

Figure 2 Selected panoramic photos from Elgegi Valley taken in the dry season, April 2015. a Area where unpalatable species dominate, the grass cover remains standing and retains a yellow-brown colour throughout the dry season. b A LSMA site covered with crop residue associated with small Acacia mellifera shrubs. c Abandoned LSMA site with no signs of natural regeneration of the vegetation 


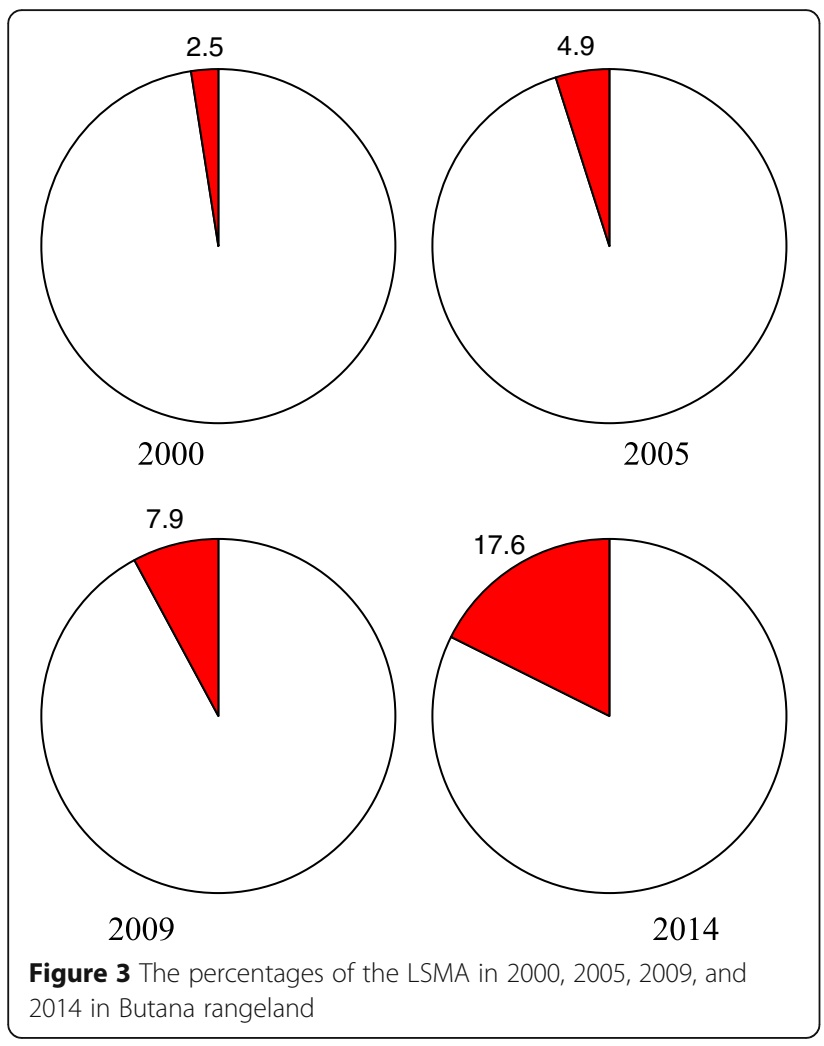

(9,486 ha) to $17.6 \%(67,594.4$ ha). Within this period, LSMA expansion occurred at varying rates. Expansion took place to the north of $1445 \mathrm{NL}$. According to the MFC, areas allocated to the north of this line have been declared as unsuitable for agriculture with the exception of lands located in the valley catchment area.

\section{Expansion of LSMA during the period 2000 to 2005}

The interpretation of imagery from 2000 shows that LSMA started gradually in the area just to the north of $1445 \mathrm{NL}$, mainly in Elgegi Valley and in the central area of Abu Grad Valley (Figure 4). During the period 2000 to 2005 , the area under LSMA doubled and covered $4.9 \%(18,817.2 \mathrm{ha})$. There was a general scattering of LSMA over the area, even in areas far from valleys.

According to key informants, settled communities in Butana practised small-scale farming in fertile soils along valleys. The soils in such locations are sedimentary and renewed by sheet floods which come from upstream in good rainy seasons. LSMA started in relatively fertile soils in areas surrounding valleys. The expansion of LSMA in the valleys has led to the uprooting of trees along the valleys (Figure 5), conflicts with local farmers over land ownership, and interrupted access of transhumant pastoralists to water in valleys because of cultivation of roads and passes. The catchment area of the valleys provides the main water source for the domestic use of pastoralists and for watering livestock during the rainy season.
Informants described the small-scale farming practised by local communities in Butana as environmentally friendly and as having no negative social implications. According to local norms and customs, farmers maintain the tree cover along valleys. The valley's trees are the main source of building materials and firewood for local inhabitants as well as the only available source of fodder for their animals during the dry season. The local land ownership system offers equal usage rights to local inhabitants in a way that sustains soil productivity.

Expansion of LSMA during the period 2005 to 2009 In 2009, the area under LSMA grew to $7.9 \%$ (30,153 ha). Most of the growth of the LSMA shown in 2009 map is in the southern part of the study area along $1445 \mathrm{NL}$ and to the northeast in the Abu Gembeel Valley. In 2009, some of the LSMA sites were no longer cultivated and had been left abandoned but were still controlled by LSFs. Informants mentioned that while local farmers keep cultivating land located in valleys continuously, LSMA land in areas away from valleys were left abandoned after about five to eight years of cultivation following poor harvests. These areas are already known by the local community as extremely marginal land not suitable for cultivation, but suitable as pastureland. Field visits to abandoned sites showed many signs of degradation, such as an increase in the percentage of gravels and large stones at the surface following mechanical soil working using heavy machinery. In some of the abandoned fields, plant species, such as Xanthium brasilicum and Datura stramonium, known by the local community as indictors of land degradation, had started to dominate. Severely degraded sites, however, remain bare with no sign of natural regeneration of the vegetation (Figure 2c).

\section{Expansion of LSMA during the period 2009 to 2014} Between 2009 and 2014, the size of the area under LSMA grew incrementally from 7.9 to $17.6 \%(67,594 \mathrm{ha})$. This rate of change reveals the rapid expansion of LSMA in Butana in recent years. According to key informants, the silence of the responsible governmental authorities has encouraged more LSFs to engage in land grabbing. A significant part of this expansion is along the southern border of the study area, while in the Abu Gembeel Valley, the area under LSMA remains almost the same. With much of the best land taken, more recent acquisition has been forced to marginal areas far from valleys. While some of the newcomers initiated their activities adjacent to the existing agricultural lands, others have selected new, isolated sites with a presumed ability to expand into the surrounding empty lands in the coming years. 

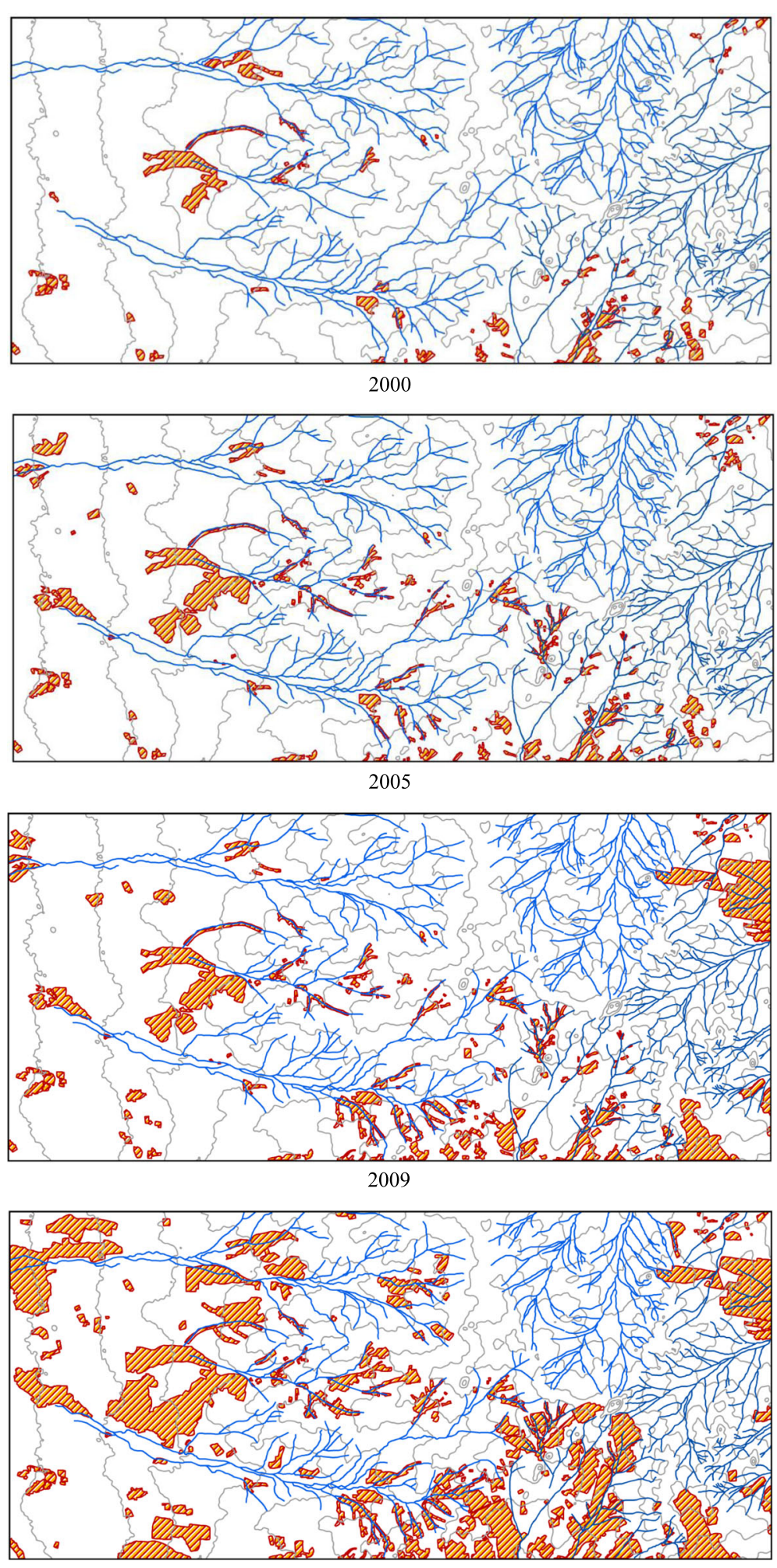

2014

Figure 4 Spatial distribution LSMA in 2000, 2005, 2009, and 2014 in Butana rangeland 


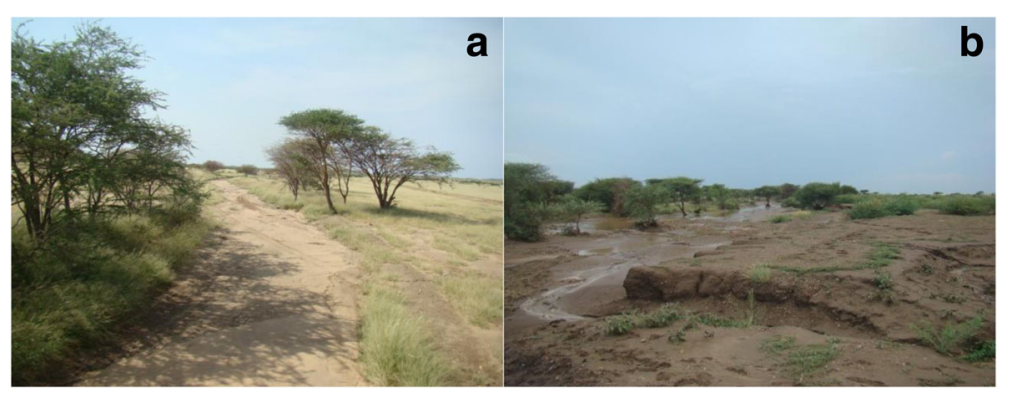

Figure 5 Comparison of cultivation practices along valleys between a small-scale farming by local inhabitants of Butana, where the tree cover has been maintained, and $\mathbf{b}$ LSMA by LSFs where the tree cover has been uprooted using heavy machinery

\section{Main features of LSFs engaged in grabbing of Butana communal rangeland}

Based on the ground surveys and key informant interviews, LSFs in the Butana area can be divided into three major categories according to their state of origin. Table 1 shows that, besides Gadarif state where the study area is located, LSFs have arrived from two neighbouring states, Kassala and Khartoum (Figure 1).

LSFs from Gadarif State were the first group to acquire land in Butana, starting in the early 1980s. Expansion began after 1996 when legislation issued by the Ministry of Agriculture in Gadarif State allowed the use of mechanized farming to $1445 \mathrm{NL}$. Although present throughout Butana, LSMA is concentrated along 1445NL. LSFs enjoy a strong institutional network with the State Assembly, Farmers' Union, MFC, Ministry of Agriculture, and loan banks. They have long experience with rain-fed agriculture, good infrastructure, and digging of water reservoirs (hafir). They are personally engaged in all agricultural practices. Besides relying on mechanical weeding, they use chemical herbicides. Crop residues are important source of income for this group.

The second major group of LSFs - a mixture of farmers and pastoralists from Kassala State - is mainly from the city of New Halfa. They started to arrive in the mid-1990s. In order to access land, they developed alliances with traditional leaders, local politicians, and related governmental departments in Kassala State. They have limited experience in rain-fed farming, although some had practised irrigated farming in the New Halfa Agricultural Scheme. These second group of LSFs include some wealthy transhumant pastoralists who visit Butana rangeland during the rainy season in their annual cycle of movement. This group of pastoralists, who combine farming with livestock rearing, own a large number of livestock. Practising LSMA in Butana is an emerging trend among these pastoral groups which consider LSMA as source of fodder production. Therefore, most do not follow crop husbandry practices, such as weeding or herbicide applications. Their interest is in the crop straw more than in the harvest. After selling the crop harvest, if any, they use the crop residues to feed their animals. Most of the land acquired by this group is located in north eastern areas which border Kassala State.

The third major LSF group, which comes from Khartoum and other major cities in neighbouring states, started land acquisition in 2010. This group has weak connections with institutions in Gadarif State and with local communities in Butana. According to Ahmed (2008), most of this group is comprised of merchants, retired army officers, and senior government officials. They tend to rent land from the first and second categories of LSFs. Because of limited experience in agriculture, these absentee farmers rely on hired representatives to manage their agricultural operations (wakil). The wakil are resident from the start of the rainy season to harvest. Most of land acquired by this group is located in the north western part of the area. They occupy land without establishing permanent infrastructure such as camps or hafir, own minimal machinery, and practise limited weed control. They use tankers and vehicles to bring in water. After harvest, they leave the crop residue to be collected for free.

\section{Discussion}

The expansion of LSMA in Butana communal rangeland and its consequences

The multi-temporal analysis of the satellite imagery presented in this study captured remarkable information on LSMA encroachment in Butana rangeland over 15 years, including its geographical context. Such analysis provides solid and timely evidence on the land grabbing currently taking place. Normally, information about land deals are scarce and difficult to access as the process is highly dynamic (Messerli et al. 2014). Therefore, spatialbased analyses which reveal local contexts and characteristics are essential for assessment. For example, the MFC has no records or maps of the current illegal LSMA presence in Butana. Thus, this study offers updated information.

The rate of the expansion of LSMA to $17.6 \%$ of the communal rangeland in Butana did not occur evenly. The most rapid expansion occurred from 2009 to 2014 


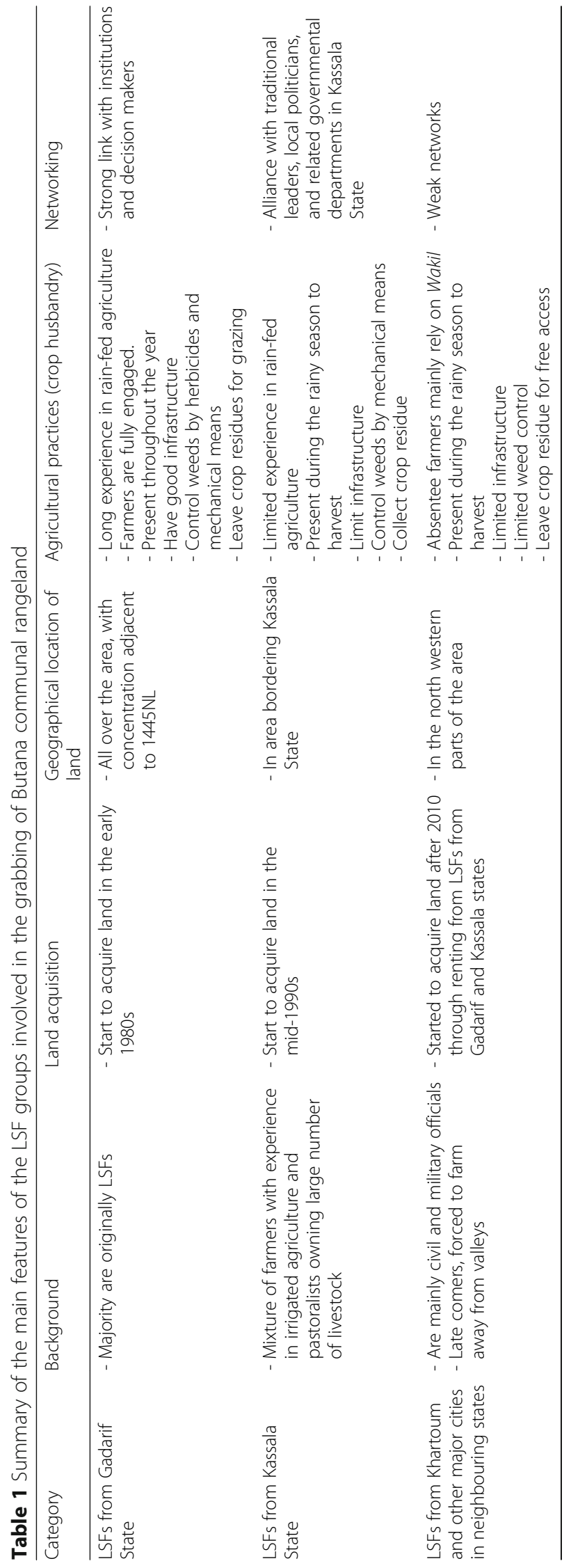


(Figures 3 and 4). This rapid expansion showed a continuation of the government's practice of turning a blind eye, attributable to the absolute power of LSFs in Gadarif State as well as to the marginalization of local land users. LSFs in Gadarif State have succeeded in building power from the community to the regional and national levels (Egemi 2008; Sulieman 2015). Babiker (2013) mentioned that the scarcity of available land in central and southern zones has meant that Butana rangeland became an alternative option for expansion in recent decades even though land-use planning had not allowed for LSMA.

The encroachment of LSMA is converting the continuous natural vegetation cover of Butana into spatially isolated patches. Such fragmentation has reduced the capacity of the rangeland to sustain the livelihood of local populations by transforming the rangeland into isolated homogeneous habitat patches that stop floral and faunal migration and reduce the ability of natural regeneration of native vegetation (Henderson et al. 1985; Laurance et al. 2001). Stokes et al. (2006) identified changing patterns of land use as the main cause of rangeland fragmentation in many developing countries. According to Behnke (2008), large agricultural investors have converted most of the valuable rangeland resources in East Africa to private intensive non-pastoral use. The spread of exclusive systems of ownership has legitimated the subdivision of communal rangelands into isolated parts. Abu Sin (1998) and Babiker (2008) wrote that the process of individualizing resource rights in Sudan has meant that rangelands have become increasingly fragmented. Access to key resources in fragmented rangeland becomes a particular challenge for pastoralists (Turner 1999). Flintan (2011) warned that the prolonged fragmentation of rangeland may likely lead to the collapse of pastoral systems. On a global scale, rangeland fragmentation has emerged as one of the components of climate change (Hobbs et al. 2008).

Part of the vegetation losses have included depletion of valuable woody shrub cover in the valleys and around seasonal water sources - the first places invaded by LSMA. Woody vegetation along streams provides a wealth of benefits, such as stability to the stream bank, reduction of water velocity, and reduction of downstream flooding, in addition to the benefits gained by local inhabitants of the area.

\section{Land acquisition by LSFs in pastoral territories}

Land acquisition for large-scale agriculture in Butana and elsewhere in Sudan has become a persistent topic in current debates on sustainable development in the country (Shazali 1993; Elhadary 2010; Babiker 2008; Sulieman 2015). After occupying the fertile soil of the central clay plains of Gadarif State, LSFs expanded their activities to the north of the official LSMA boundary of 1445NL. In North Kordofan State (Sudan), the limit is $13^{\circ} \mathrm{NL}$. In Niger, according to the 61 Code Pastoral of 1961, all territory above $15^{\circ} \mathrm{NL}$ is declared pastoral zone (Oxby 2011). According to Hesse and Thébaud (2006), various pastoral laws have been passed in many Sahelian countries, such as Guinea, Mauritania, Mali, and Burkina Faso, yet never strictly enforced. This situation, prevalent in many African countries, reflects the real position of pastoralist populations as politically and economically marginalized. The LSFs engaged in land acquisition activities in Butana argue that the land is empty and unowned. Babiker (2013) found that as a result of the expansion of LSMA north of its official zone, pastoralists were squeezed onto drier rangelands which are typically furthest from water sources. According to Gilbert (2007), the rules governing land use and ownership in modern societies have been framed around cultivation of land as the proper occupation of land and, therefore, the basis for any land tenure system. Consequently, territories used by mobile pastoralists or non-sedentary agriculturists are to be regarded as vacant.

As discussed, the LSFs currently involved in the expansion of LSMA in Butana communal rangeland comprise three groups (Table 1). The largest group comes from Gadarif State where LSMA has been practised since 1945 and promoted by official land-use policy and planning (Babiker 2008). In Gadarif, the 1970 Unregistered Land Act declared state ownership of all unregistered lands. The act provided a legal basis for land acquisition which dispossessed local communities of their customary land rights (Sulieman 2015). Ohlson and Söderberg (2002) cite Sudan as an example of a weak state in which some groups of inhabitants systematically and over time dominate or threaten the security of other groups and communities which the central government has failed to protect.

Illegal occupation of land is not new for LSFs in Gadarif State. Their general strategy has been to occupy first and then seek legalization using their power and networks with relevant institutions. Sulieman (2015) mentioned that in 1996, the Gadarif State Minister of Agriculture issued an act which legalized the illegal cultivation activities north of $14^{\circ} 37^{\prime} \mathrm{NL}$, the northern limit of LSMA at that time.

Wealthy pastoralists who own large numbers of livestock comprise the second group of LSFs grabbing Butana communal rangeland. Some pastoralists benefit from the current land grabbing while others are losing out. In general, those who benefit integrate LSMA with traditional pastoralism. They have assets on hand and a broad network at their disposal which they can use to influence decision makers, enclose property, build herds, and diversify. Ahmed (2008) gave an example from Blue Nile State (Sudan) where some pastoral groups have 
rapidly been diversifying their economies with LSMA as one of the preferred options. The concept of individually controlled land brought to the communal rangeland by LSFs has encouraged some pastoral elites to grab resources for their own herds. Such behaviour has created tensions within pastoral groups that are split by differences in wealth and status (Babiker 2013).

The absentee farmers who comprise the third group of LSFs in Butana (Table 1) are not new in Gadarif. The way they manage their activities in areas that they have occupied in Butana matches the description given by El-Tayeb (1985) about this class of LSFs elsewhere in Gadarif. They are hesitant to construct permanent buildings or invest in equipment because of the uncertainty of the renewal of land ownership or renting contracts; therefore, they maintain a minimum standard of crop husbandry. Such approaches have caused farming to become a kind of extractive agriculture.

\section{Conclusions}

Sudan is among the global 'hotspots' for large-scale land acquisition. However, scant empirical evidence exists on the spatial distribution and temporal evolution of the process. Multi-temporal satellite imagery combined with ground surveys and interviews with key informants effectively captures the illegal rapid expansion of LSMA in Butana rangeland by LSFs. This expansion may make LSMA the major threat challenging the existence of communal rangeland and its traditional users. Converting communal rangeland to individually controlled farms fragments the rangeland, in turn reducing its capacity to sustain local populations and the natural regeneration of native vegetation.

Although the current expansion of LSMA in Butana rangeland is illegal according to rules set by the governmental authorities responsible for leasing farmland, LSFs continue to occupy new land at the expense of smallholders and pastoralists. This situation has shown the extent of power of the farmers as reflected in the political and economic marginalization of traditional land users. Without representative institutions, traditional land users cannot defend their tenure rights. This is a long-standing problem in Sudan, and the failure of ensuring open access to pastoral resources has triggered conflicts in many parts of the country. A better understanding of customary patterns of mobile pastoralism is key to preventing continued conflict.

LSFs involved in contemporary land grabbing in Butana are mainly from major urban centres. This process of elite capture, based on an extractive model of land use and driven by economic interest, is weakening the systems where mobile pastoralists use open-access grazing resources which are highly variable in space and time. Access to communal rangeland is a determining factor in the survival of the pastoral lifestyle.
This study offers empirical evidence that identifies, quantitatively, the evolution of land-grabbing processes in communal rangeland. It also supports local reactions and the initiatives of alliances of governmental and nongovernmental institutions to advocate for the preservation of rangeland. The current experience from communal rangeland grabbing, presented in this paper, has a direct relevance and strong connections to many pressing issues already prevalent in the country, such as land degradation, desertification, climate change, and social conflicts. Without a fundamental change in development policies in Sudan, land-based conflict, taking place in many parts of the country, may also erupt in its eastern parts.

\section{Funding}

Not applicable.

\section{Author's contributions}

The author read and approved the final manuscript.

\section{Competing interests}

The author declares that he has no competing interests.

\section{Publisher's Note}

Springer Nature remains neutral with regard to jurisdictional claims in published maps and institutional affiliations.

Received: 9 October 2017 Accepted: 13 February 2018

Published online: 24 April 2018

\section{References}

Abbink J., Askew K, Dori D. F., Fratkin E, Gabbert EC, Galaty J, LaTosky S, Lydall J, Mahmoud HA, Markakis J, Schlee G, Strecker I, Turton D. 2014. Lands of the future: Transforming pastoral lands and livelihoods in Eastern Africa. Max Planck Institute for Social Anthropology Working Papers. Working paper no. 154. ISSN 1615-4568.

Abu Sin, M. 1998. Custodians of the commons: Pastoral land tenure in East and West Africa. Earthscan in the UK, 120-149.

Ahmed A. G. M. 2008. Transforming pastoralism: A case study of the Rufa'a al Hoi Ethnic Group in the Blue Nile State, Sudan. Chr. Michelsen Institute: Bergen, SWP 2008: 1.ISBN 978-82-8062-224-2.

Al-Bilbisi, H.H. 2012. A two-decade land use and cover change detection and land degradation monitoring in central Jordan using satellite images. Jordan Journal of Social Sciences 5: 2012-2133.

Alkan M., Oruç M., Kayabaş D., Sefercik U. G. 2010. Spatial and temporal GIS analysis of change detection using IKONOS images: A case study of Zonguldak. ISPRS Istanbul Workshop 2010 on modelling of optical airborne and spaceborne sensors, WG I/4, Oct. 11-13, IAPRS Vol. XXXVIII-1/W17.

Babiker, M. 2008. Communal land rights and peace-building in north Kordofan: Policy and legislative challenges. In Sudan Working Paper: 3. Bergen: Bergen. Chr. Michelsen Institute.

Babiker, M. 2013. Mobile pastoralism and land grabbing in Sudan: Impacts and responses. In Pastoralism and development in Africa: Dynamic change at the margins, ed. A. Catley, J. Lind, and I. Scoones. Routledge Taylor \& Francis Group: ISBN:978-0-415-54072-8.

Behnke R., Kerven C. 2013. Counting the costs: Replacing pastoralism with irrigated agriculture in the Awash Valley, Northeastern Ethiopia. IIED climate change working paper no. 4.

Behnke, R.H. 2008. The drivers of fragmentation in arid and semi-arid landscapes. In Fragmentation in semi-arid and arid landscapes consequences for human and natural systems, ed. K.A. Galvin, R.S. Reid, R.H. Behnke, and N.T. Hobbs, 305-340. Dordrecht: Springer ISBN: 978-1-4020-4905-7.

Bernal, V. 1997. Colonial moral economy and the discipline of development: The Gezira scheme and "modern" Sudan. Cultural Anthropology 12 (4): 447-470.

Campbell, J.B. 2006. Introduction to remote sensing. Fourth ed. New York: Taylor \& Francis ISBN10: 0-415-41688-4. 
Casciarri, B. 2002. Local trends and perceptions of processes of commoditisation in central Sudan: The responses of the Ahamda pastoral system to state pressures and capitalist dynamics (1). Nomadic Peoples 6: 32-50. https://doi. org/10.3167/082279402782311158.

Catley, A., J. Lind, and I. Scoones, eds. 2013. Pastoralism and development in Africa: Dynamic change at the margins. Routledge: Abingdon and New York

Cotula, L. 2011. Land deals in Africa: What is the contracts? London: IIED ISBN: 978-1-84369-804-3.

Deininger, K., D. Byerlee, J. Lindsay, A. Norton, H. Selod, and M. Stickler. 2011. Rising global interest in farmland: Can it yield sustainable and equitable benefits? Washington DC: World Bank.

Disperati, L., S. Gonario, and P. Virdis. 2015. Assessment of land-use and land-cover changes from 1965 to 2014 in Tam Giang-CauHai Lagoon, central Vietnam. Applied Geography 58: 48-64. https://doi.org/10.1016/j.apgeog.2014.12.012.

Egemi O. 2008. Securing pastoralism in East and West Africa: Protecting and promoting livestock mobility, Sudan in-depth study. IIED/SOS Sahel Intl UK, 2008.

Elhadary, Y., and H. Abdelatti. 2016. The implication of land grabbing on pastoral economy in Sudan. World Environment 6 (2): 25-33. https://doi.org/10.5923/j. env.20160602.01

Elhadary, Y.A.E. 2010. Challenges facing land tenure system in relation to pastoral livelihood security in Gedarif State, Eastern Sudan. Journal of Geography and Regional Planning 3: 208-218.

El-Tayeb G. 1985. The Gedarif study area. Institute of Environmental Studies: University of Khartoum, Khartoum.

Flintan F. 2011. "Broken lands: Broken lives?" causes, processes and impacts of land fragmentation in the rangelands of Ethiopia, Kenya and Uganda. 2011. For REGLAP (Regional Learning and Advocacy Programme): Nairobi.

Galaty, J.G. 2013. Land grabbing in the eastern African rangelands. In Pastoralism and development in Africa: Dynamic change at the margins, ed. A. Catley, J. Lind, and I. Scoones, 143-153. Abingdon and New York: Routledge.

Gilbert, J. 2007. Nomadic territories: A human rights approach to nomadic peoples' land rights. Human Rights Law Review. https://doi.org/10.1093/hrlr/ngm030.

Henderson, M.T., G. Merriam, and J. Wegner. 1985. Patchy environments and species survival: Chipmunks in an agricultural mosaic. Biological Conservation 31: 95-105. https://doi.org/10.1016/0006-3207(85)90043-6.

Hesse C., Thébaud B. 2006. Will pastoral legislation disempower pastoralists in the Sahel? Indigenous Affairs1/06. http://drylands-group.org/publications/willpastoral-legislation-disempower-pastoralists-in-the-sahel. Accessed $10 \mathrm{Mar}$ 2018.

Hobbs, N.T. K.A. Galvin, C.J. Stokes, J.M. Lackett, A.J. Ash, R.B. Boone, R.S. Reid, and P.K. Thornton. 2008. Fragmentation of rangelands: Implications for humans, animals, and landscapes. Global Environmental Change 18: 776-785.

Krätli, S., C. Huelsebusch, S. Brooks, and B. Kaufmann. 2013. Pastoralism: A critical asset for food security under global climate change. Animal Frontiers 3: 42-50. https://doi.org/10.2527/af.2013-0007.

Laliberte, A.S., M.A. Goforth, C.M. Steele, and A. Rango. 2011. Multispectral remote sensing from unmanned aircraft: Image processing workflows and applications for rangeland environments. Remote Sensing 3: 2529-2551. https://doi.org/10.3390/rs3112529.

Laurance, W.F., G.B. Williamson, P. Delamonica, A. Olivera, and C. Gascon. 2001. Effects of a strong drought on Amazonian forest fragments and edges. Journal of Tropical Ecology 17: 771-785.

Markakis, J. 1998. Resource conflict in the horn of Africa. London: Sage Publications.

Messerli, P., M. Giger, M.B. Dwyer, T. Breu, and S. Eckert. 2014. The geography of large-scale land acquisitions: Analysing socio-ecological patterns of target contexts in the global South. Applied Geography 53: 449-459. https://doi.org/10.1016/j.apgeog.2014.07.005.

Müller, C., K. Waha, A. Bondeau, and J. Heinke. 2014. Hotspots of climate change impacts in sub-Saharan Africa and implications for adaptation and development. Global Change Biology. https://doi.org/10.1111/gcb.12586.

Ohlson T., Söderberg M. 2002. From intra-state war to democratic peace in weak states. Issue 5 of Uppsala Peace Research papers, ISSN 1650-2035.

Oxby, C. 2011. Will the 2010 "code pastoral" help herders in central Niger? Land rights and land use strategies in the grasslands of Abalak and Dakoro Departments. Nomadic Peoples 15: 53-81. https://doi.org/10.3167/np.2011.150205.

Pantuliano, S. 2007. The land question: Sudan's peace nemesis. Humanitarian policy group working paper. Overseas Development Institute: London.

Schlee, G. 2013. Why state still destroy pastoralism and they can learn that in their own interest they should not. Nomadic people 17: 6-19. https://doi.org/10.3167/np.2013.170203.
Shazali, S. 1993. Pastoral vulnerability, environmental degradation and state policy: The case of south Kassala, Sudan. In Paper IVth OSSREA Congress on the Global Nature of the Environmental Crisis and its Interrelationship with Development: Africa's plight. August 9-12, 1993, DebreZeit, Ethiopia.

SKAP. 1992. Land use survey report (main report). Khartoum: Government of the Sudan.

Stokes, C.J., R.R.J. McAllister, and A.J. Ash. 2006. Fragmentation of Australian rangelands: Processes, benefits and risks of changing patterns of land use. Rangeland Journal 28: 83-96.

Sulieman, H.M. 2015. Grabbing of communal rangelands in Sudan: The case of large scale mechanized rain-fed agriculture. Land Use Policy 47: 439-447. https://doi.org/10.1016/j.landusepol.2015.04.026.

Sulieman, H.M., and A.M. Ahmed. 2016. Mapping the pastoral migratory patterns under land appropriation in East Sudan: The case of the Lahaween ethnic group. The Geographical Journal. https://doi.org/10.1111/geoj.12175.

Turner, M.D. 1999. The role of social networks, indefinite boundaries and political bargaining in maintaining the ecological and economic resilience of the transhumance systems of Sudan-Sahelian West Africa. In Managing mobility in African rangelands, ed. M. Niamir-Fuller, 97-123. London: FAO and Beijer International Institute of Ecological Economics.

UNEP. 2007. Sudan: Post-conflict environmental assessment. Nairobi: United Nations Environment Programme.

Vitanen, E. 1982. Nomadism and desertification: A case study of northern Kordofan, Sudan. Nomadic Peoples 10: 58-60.

World Bank. 2010. Rising global interest in farmland: Can it yield sustainable and equitable benefits? Washington, DC: World Bank.

\section{Submit your manuscript to a SpringerOpen ${ }^{\circ}$ journal and benefit from:}

- Convenient online submission

- Rigorous peer review

- Open access: articles freely available online

- High visibility within the field

- Retaining the copyright to your article

Submit your next manuscript at $>$ springeropen.com 